Xuan He

\title{
Symbiotic Relationship of Modern Contract and Traditional Ethic: Entrepreneur's Zhongyong Rationality and Family Firm Governance Choice
}

\author{
(C) Higher Education Press and Springer-Verlag 2011
}

\begin{abstract}
What is the relationship between Chinese familism and the modern economic organization? Can a rational, contractual relationship grow out of Chinese familism that widely exists in Chinese family businesses? This paper holds that Chinese familism can nurture a rational and contractual relationship. However, such a relationship is not an extremely instrumental rationality of Logocentrism, but a zhongyong rationality characteristic of Confucian culture essence. This paper verifies empirically for the first time the existence of zhongyong rationality by analyzing family entrepreneurs' governance choices. The results reveal that under the guidance of zhongyong rationality, entrepreneurs in Chinese family firms lay more emphasis on restraints than on efficiency, balance the interests among the management, the firm and the owning family, and maintain equilibrium between the insiders and outsiders. This research also finds that a shift from instrumental rationality to zhongyong rationality can provide more satisfactory and indigenous explanations to some phenomena widely in existence among Chinese family firms, as compared with corresponding Western theories.
\end{abstract}

Keywords family firm, family business entrepreneurs, instrumental rationality, zhongyong rationality

Received June 25, 2010

Xuan $\mathrm{He}(\bowtie)$

School of International Economic \& Trade, Guangdong University of Foreign Studies, Guangzhou 510006, China

Chinese Family Firm Research Center, Sun Yat-sen University, Guangzhou 510275, China

E-mail: hinland@163.com 


\section{Introduction}

Weber (1955) proposed that China's familism is detrimental to the formation of modern economic organizations. Feng (2001) also held that China's industrialization would inevitably bring an end to China's familism. The status quo of China's economic progress and the popularity of family-run firms in China, however, presents a serious challenge to the above propositions. Zhai (2001) argued that, based on his field research on zhouzhuang, a small town in the south of Suzhou province, there might exist a certain symbiotic relationship between China's familism and modern economic organizations. If China's familism is capable of naturing a certain rational, more contract-based (i.e., less blood-based) relationship, what is the nature of such a relationship? Or, in other words, what kind of rationality is it? This paper argues that the rationality is by nature a zhongyong rationality consisting of both elaboration in business management and pursuit of power, rather than a Logocentrism type of instrumental rationality in its ideal state.

This paper aims to verify the existence of zhongyong rationality in Chinese familism by studying the choice of governance modes of family-run firms. Considering China's current low level of social trust, most family firms rely on a family-member-based "governance mode," particularly at their early development stage. However, the marginal utility of such a mode decreases quickly or even become negative as these firms mature. If instrumental rationality is considered when choosing governance mode, family firms would put efficiency as a top priority and apply contract-based governance mode to both family and non-family firm members. Contrary to their foreign peers, most Chinese family firms, under the guiding philosophy of zhongyong rationality, tend to lay more emphasis on restraints than on efficiency, and endeavor to balance the interests among the management, the firm and the owning family, and to maintain equilibrium between the insiders and outsiders. Chinese family firms have found that adopting an extreme utilitarian governance approach in firms to maximize profitability, regardless of family members or non-family members, would lead to an obvious decrease in holistic utility of both owning family members and the management. Therefore, out of emotional reasons, most of the Chinese family firms would not choose to abandon redundant family employees. Even to those family members who are now become hindrance to firm development, family firms tend to adopt a "retain but keep an eye on" strategy towards these "black sheep." Meanwhile, entrepreneurs in family firms endeavor to maintain a delicate balance between insiders and outsiders, maximizing the two parties' interests by taking into consideration both "emotion and rationality."

Based on the above rationale, we argue that a shift from instrumental 
rationality to zhongyong rationality provides an "indigenous" answer to some of the long-existing phenomena that usually cannot be explained by imported western theories in Chinese family firms. Such a shift could help us gain a better understanding of the rational behaviors of entrepreneurs in Chinese family firms.

\section{Theories and Hypotheses}

\subsection{Instrumental Rationality and Governance Mode of Family Firms in China}

Being an important contributor to China's economic miracle, Chinese entrepreneurs' value and behaviors wield enormous influence on people's economic behaviors, and eventually affect China's overall socioeconomic development. The founders of behavioral economics, Tversky and Kahneman (1974) pointed out that the driving factors behind individual behaviors include not only interests, but also value, faith, and other individual characteristics. As the actual controller, the value of the entrepreneurs in family firms are likely to lay great impact on the choice of governance mode in their enterprises. This is why this paper discusses choice of governance mode from the perspective of an entrepreneur's rationality.

King (1992) studied family firms in Hong Kong and found that employment decision of relatives in these firms is made based on utility of "cultural resources." He thus defined such an employment as a utility-based "rational choice," or a "rational traditionalism." Similarly, Yang (2006) held that although there exists a path dependency between cultural inertia and organizational system, many decisions in family firms are rational choices, rather than cultural choices. Pang (2006) confirmed that though they might receive certain preferential treatment in obtaining employment opportunities, most of the members in the founding family of family firms enjoy no priority over other non-family members in competing for managerial positions.

Pang asserted that it is a necessary transition for family firms to switch to instrumental rationality. As Weber (1997: 56) defined it, instrumental rationality is "behavior oriented to means considered adequate to attain clearly comprehended ends." "Action is instrumentally rational...when the end, the means and the secondary results are all taken into account and weighed. This involves rational consideration of alternative means to the end, of the relations of the end to secondary consequences, and finally of the relative importance of different possible ends." In other words, people of instrumental rationality tend to regard behavior as an effective means to maximize benefits and minimize costs. Therefore, instrumental rationalists tend to regard other people or things as either instrument or hindrance to their success. By comparison, instrumental rationality is most typical in market behaviors. 
We believe that entrepreneurs of family firms are less likely to adopt instrumental rationality - a family firm is a combination of family and firm, which consists of both family employees and non-family employees. Managers of family firms therefore have to balance the interests between "outsiders" and "insiders." In this sense, the governance of family firm is quite different from that of other types of firms. We hence argue that the perspective of zhongyong rationality, as an indigenous philosophy, might be a more suitable perspective for studying Chinese family firms.

\subsection{Zhongyong Rationality and Corporate Governance of Family Firms}

Though widely accepted and practiced in China as an indigenous philosophical concept, there has been little academic research, in the strict sense, on the term of zhongyong, let alone quantitative research.

The 2008 global financial crisis makes people more aware of the danger of pure instrumental rationality in modern economic organizations. In a sense, the breakout of the crisis is partly because of the abuse of financial derivative instruments that rooted in the assumption of "rational economic man." By contrast, the economy in Eastern countries remained relatively stable during the crisis. One plausible explanation might be their emphasis on stability and balance in Confucian culture helped achieve a restrained efficiency in oriental economics.

To date, there has been little attempt to operationalize the concept of zhongyong, despite the call for "routinization of Confucian philosophy in life" (Yu, 2005: 254-255). Similarly, Yang (2001: 271) considered zhongyong as a "pattern of thinking which can guide people to gain deeper understanding of the problem they encounter in their daily life and help people to figure out better solutions."

The concept can be understood in the following ways. Firstly, zhongyong is a cognitve framework of people and things. It views things as in a dynamic state of existance on a value dimension with two ends, and advocates the avoidance of going to the extremes based on the belief that too much of good could have negative consequences. Second, zhongyong believes that the purpose behind any action is to reach a dynamic and harmonious state. Third, zhongyong is a set of decision criteria for actions. Individuals holding zhongyong thoughts follow certain thinking principles, such as pursuit of harmony, a holistic view, moderation, and balance. Fourth, zhongyong can also be considered behavioral characteristics. Individuals holding zhongyong thoughts are characterized by (1) emphasis of self-discipline, (2) holistic approach to thinking and planning, (3) selection of appropriate plan in accordance with the specific context, (4) constant modification of plans by means of introspection and feedback iteratively, to achieve the ideal outcome. (5) above all, zhongyong thoughts are a zhongyong 
rationality rather than an instrumental rationality.

In their research on the choice of corporate governance of family firms, He et al. (2008) identified different corporate governance modes suitable for different type of agents. They also provided preliminary empirical evidence to the relationship between different corporate governance modes and firm performance. He et al.'s research, however, did not discuss the reasons behind the choice of different corporate governance modes, nor did they analyze independent variables for governance mode. Such limitations are actually common in the extant literature on different governance modes. Behavioral economists argue that classical economic theories shall be further amended in terms of theoretical preconditions, theory formation and results testing. Specifically, they believe that economic theories need to take into consideration more findings from psychology, sociology, anthropology, organizational theories and decision science, so as to make theoretical hypotheses in economics stronger. In terms of theory formation, behavioral economists assert that economics shall highlight explanation of observed behaviors, rather than logical conditions for behavior occurrence; and in results testing, economics need to introduce into itself diversified empirical study approaches, such as field survey or data analysis (Liu and Jiang, 2004).

Tversky and Kahneman (1974) pointed out that individual behaviors are motivated by a number of variables such as value, personal beliefs, and individual characteristics, rather than by personal interests alone. Comparatively speaking, transaction cost economics stresses more on semi-micro analytic contractual phenomenon, while behavioral economics analyzes the very decision-making behavior of micro entities and generalizes rules deduced from individual behaviors upwards to a more macro level. Furthermore, transaction cost economics explains economic phenomenon via contractual relationship, while behavioral economics is more interested in the decision-making modes and interaction among the parties involved. To sum up, behavioral economics gives priority to interaction among people, making it a more practical economics. This paper is an extension of $\mathrm{He}$, Chen and $\mathrm{Li}$ (2008). By introducing into family firm governance a theoretical foundation of behavioral economics, we hope to better depict the vivid interaction among all family members.

\subsection{Hypotheses Development}

As family employees are linked to a family firm owner by blood or kinship, and they have long shared the same social network, it is possible for these employees and firm owners to share a lot of similarities in many things, values, and views. Family firm owners are therefore likely to, particularly at the start-up stage of their firms, bind all family employees with affectional ties, so as to reduce 
agent-principal costs. However, as firms mature, the marginal utility of such a relationship-based governance mode reduces steadily, or even lead to negative marginal utility in some extreme cases.

$\mathrm{He}$ and Zhu (2008) found that altruism in family firms cultivates a mutual loyalty among family members, which helps unite all family members together in their creation of more family wealth. The reason behind might be that altruism makes family member feel they have certain residual claims over family wealth, they would therefore willing to make sacrifice for family's long-term interests. Altruism also facilitates the spread of some family secrets among family members, such an additional information conveying channel help smoothen decision-making process in family firms. As mentioned earlier, relationship-based governance might also lead to negative marginal utility, which is likely to be ignored during the process of early firm development. Schulze et al. (2001) designed, based on existing literature on altruism and self-control, an agency cost model for family firm. Contrary to Jensen and Meckling's assumption (1976), they found that a combination of ownership and management rights leads to higher agency cost due to information asymmetry: altruism of family patriarch is likely to produce "spoiled children." Unilateral altruism also leads to unfair distribution of family wealth as a result of information asymmetry: Resources are allocated to insiders rather than to people who contribute most to firm development. Moreover, as family firm matures, such altruism-based relational governance mode might give rise to more problems, such as rent-seeking activities.

The question is, considering all the problems relational governance mode might induce, why are there still a majority of family firms that prefer this informal "insider first" governance mode? The answer is: Entrepreneurs in family firms are aware that a "get-down-to-business-first" mentality or instrument-oriented managerial style will certainly lead to hatred and unrest among family members. In addition, such an approach is inconsistent with Chinese people's belief of "harmony in the family leads to prosperity in all undertakings," thus would be regarded as a short-sighted move. In addition, when facing crisis, the loyalty of family members tends to be higher than that of the non-family employees. Therefore, although cross-sectional data does not indicate a positive relationship between an insider-based governance mode and decision quality, it does not mean that family employees are of no use to family firms. Moreover, Chinese people have traditionally disrelished the practice of "kick off the ladder." If the entrepreneurs in family firms are too utilitarian-oriented and ignore the emotion and interests of family employees in their firms, it would reduce rather than increase the holistic effects in firms. Therefore, out of emotional reasons, entrepreneurs in family firms holding the "zhongyong rationality" are more likely to be more tolerable to family employees, 
as compared with to non-family employees. Even for family employees who are of no contribute to firm development, entrepreneurs of family firms would help these employees gain further development than simply dismiss them. Similarly, even for family employees who have become hindrance to firm development, entrepreneurs are prone to adopt a "retain but keep an eye on" strategy toward them. Drawing upon the above rationale, we propose the following hypotheses:

H1a There is no significantly positive relationship between relational governance on insiders and the quality of firm decisions.

H1b The zhongyong rationality of entrepreneurs in family firms is significantly and positively related to relational governance on insiders.

$\mathrm{He}$, Chen and $\mathrm{Li}$ (2008) found that both contractual governance on insiders and relational governance on outsiders are positively related to decision quality in family firms. However, they also found that the percentage of shares held by professional managers is not positively related to decision quality. They thus argued that it is the zhongyong rationality that is behind the choice of governance mode of entrepreneurs in family firms.

However, family firms are not likely to ignore their profit goals. Therefore, entrepreneurs holding zhongyong rationality need to compensate the shortcomings of insider-based governance with formal contractual governance, including carefully-designed service-for-equity arrangements and establishment of board of directors. By introducing into family firms contractual governance, ordinary family employees gain an access to strategy making process, thus improving family employees' acceptance to decisions made. To sum up, contractual governance on family employees facilitates the supervision and control over these employees and thus decision quality in family firms is improved accordingly.

As for governance on outsiders, the positive effect of future options having on firm performance only works under a series of preconditions, including the maturity of the professional manager market, indoctrination of career ethics by professional managers, establishment of well-designed insider governance mechanisms, and above all, change of the old ideas of founding family members. None of these preconditions, however, is ready in China, particularly in terms of the professional manager market and business ethics. As a result, future options that are supposed to go to professional managers are vulnerable to insider tunneling activities. Taking all this background information into consideration, we assume that the choice of insider-based governance by a majority of entrepreneurs in Chinese family firms is basically a rational move, rather than simply out of the reason of firm controlling. Currently, by adopting a pan-familism governance mode, family firms can increase the turnover cost of professional managers and enhance their loyalty and sense of belongings by 
converting these managers into insiders.

We thus propose that

H2a Contractual governance on insiders is positively related to decision quality in family firms.

H2b The zhongyong rationality of entrepreneurs in family firms is positively related to contractual governance on insiders.

H3a Relational governance on outsiders is positively related to decision quality in family firms.

H3b The zhongyong rationality of entrepreneurs in family firms is positively related to relational governance on outsiders.

H4a There is no positive relationship between the percentage of shares held by professional managers and decision quality in family firms.

H4b There is no positive relationship between the zhongyong rationality of entrepreneurs in family firms and the percentage of shares held by its professional managers.

The theoretical model of this study is designed as follows: Model 1 divides governance modes in family firms into four subtypes in accordance with four dimensions, namely insider, outsider, relational governance and contractual governance, so as to test which governance mode is more beneficial to firm performance; Model 2 aims to test how do entrepreneurs holding zhongyong rationality make their choice of governance mode.

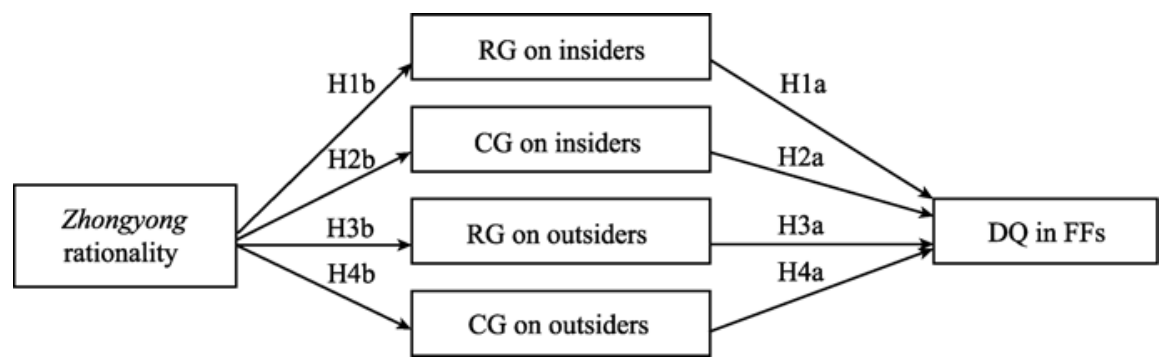

Fig. 1 Research Model for Zhongyong Rationality of Entrepreneurs in Family Firms and Their Choice of Governance Mode

Note: $\mathrm{RG}=$ relational governance, $\mathrm{CG}=$ contractual governance, $\mathrm{DQ}=$ decision quality, $\mathrm{FF}=$ family firms.

\section{Research Method}

\subsection{Data Collection}

As the current study involves data concerning entrepreneurs in family firms, all questionnaires were distributed through personal connections of either the author 
or his friends with participating entrepreneurs. After a small-scale pilot study, we started distributing the modified version of questionnaire during the time period from September 2008 to January 2009. 203 questionnaires out of 230 were returned. Among them, 178 copies were valid ones (response rate $=87.7 \%$ ). The participating firms' geographical distribution were Guangdong province $42.1 \%$, Shandong province $24.2 \%$, Jiangsu province $14 \%$, Beijing $7.9 \%$, Ningxia Hui Nationality Autonomous Region 5.6\%, Shanghai $2.8 \%$, and other provinces and regions $3.4 \%$, as shown in Table 1 .

Table 1 Statistical Description of Sample Firms

\begin{tabular}{|c|c|c|c|c|c|c|}
\hline & $\begin{array}{r}\text { Firm } \\
\text { age }\end{array}$ & $\begin{array}{l}\text { Entrepreneur } \\
\text { age }\end{array}$ & $\begin{array}{l}\text { Entrepreneur } \\
\text { gender }^{\mathrm{a}}\end{array}$ & $\begin{array}{l}\text { Entrepreneur } \\
\text { education } \\
\text { level }^{\text {b }}\end{array}$ & $\begin{array}{l}\text { Establishment } \\
\text { of board of } \\
\text { directors }\end{array}$ & $\begin{array}{l}\text { No. of } \\
\text { employees }\end{array}$ \\
\hline \multirow{2}{*}{$\begin{array}{l}\text { Sample } \\
\text { firm }\end{array}$} & 170 & 161 & 167 & 175 & 172 & 168 \\
\hline & 8 & 17 & 11 & 3 & 6 & 10 \\
\hline Mean & 9.979 & 39.120 & 0.830 & 3.010 & 0.470 & 207.770 \\
\hline $\mathrm{SD}$ & 6.800 & 7.865 & 0.417 & 1.155 & 0.500 & 556.628 \\
\hline Minimum & 1.0 & 20 & 0 & 1 & 0 & 3 \\
\hline Maximum & 58.0 & 59 & 1 & 5 & 1 & 6000 \\
\hline
\end{tabular}

Note: a. $0=$ female, $1=$ male.

b. 1 = junior high school and below; 2 = senior high school; $3=$ three-year college; $4=$ bachalor degree; 5 = master degree or above.

\subsection{Variable Measurements}

The measure of governance on insider/outsider was developed based on He et al. (2008). Mustakallio, Autio and Zahra (2002) found contractual governance and relational governance can exist side by side in family firms and exert joint impact on the firms' strategy decision making. Their scale included items concerning social interaction and information communication. Drawing upon their study, this research included the two items in measuring specific governance mode on insider/outsider in family firms (as shown in the following EPA part; items for measuring decision quality (as an indicator for strategy performance) were adopted from corresponding studies of Dooly, Fryxell (1999) and Mustakallio (2002).

Items for measuring zhongyong rationality were adopted from relevant studies 
of Yang and Chiu (1997) and Chiu (2000). Each item in the scale describes two opposite scenarios, one indicates zhongyong rationality (1) and the other for non-zhongyong rationality (0). The total score of all 16 items was the final mark for each entrepreneur.

\section{Data Analysis}

\subsection{Exploratory Factor Analysis}

To test the construct validity of the three constructs, namely relational governance on insiders, contractual governance on insiders, and contractual governance on outsiders, we used SPSS 15.0 to conduct an EFA. The results showed that KMO equaled 0.863 , indicating that a satisfactory construct validity. Our model also passed the Bartlett's Test, indicating that the factor model is appropriate. Therefore, data collected in this study were suitable for EFA. The later iterative principal factor analysis identified three factors with eigenvalue bigger than 1 . The three factors after varimax orthogonal rotation are listed in Table 2 (62.635\% of the total variance explained).

As for discriminant validity, we adopted Fornell and Larcker's (1981) method: the average variance extracted (AVE) for all factors shall be bigger than the square of inter-factor correlation. As shown in Table 3, a vast majority of factors extracted meet this requirement (except the correlation between zhongyong rationality and contractual governance).

\subsection{Regression Analysis}

SPSS 15.0 was adopted to conduct regression analysis on the hypotheses proposed. The results are listed in Table 4. As shown, H2a was not supported, indicating that contractual governance on insiders is not significantly related to decision quality in family firms. H1a, H3a, and H4a were all supported by our empirical findings. Particularly, we found that the relationship between relational governance on insiders and decision quality is significantly negative, rather than significantly positive; $\mathrm{H} 1 \mathrm{~b}, \mathrm{H} 3 \mathrm{~b}$, and $\mathrm{H} 4 \mathrm{~b}$ were also supported. Particularly, we found that entrepreneurs holding zhongyong rationality in China dislike granting stock options to professional managers $(b=0.615$, significant at 0.01 level).

\subsection{Common Method Variance}

As the above results were based on self-reported data, we adopted Padsakoff et al.'s (2003) method to detect the common method variance (CMV). Specifically, we entered all items in our questionnaires in the factor analysis, the first principal 
factor prior to rotation was the value of CMV. Our test showed that the first principal factor was $35 \%$, a value not big enough to affect the credibility of our conclusions.

Table 2 Factor Loading Matrix and Testing of Construct Validity

\begin{tabular}{|c|c|c|c|}
\hline \multirow[b]{2}{*}{ Item } & \multicolumn{3}{|c|}{ factor } \\
\hline & $\begin{array}{l}\text { RG on } \\
\text { insiders }\end{array}$ & CG on insiders & $\begin{array}{c}\text { CG on } \\
\text { outsiders }\end{array}$ \\
\hline $\begin{array}{l}\text { You always communicate with your family } \\
\text { employees about job-related information }\end{array}$ & 0.842 & 0.188 & 0.061 \\
\hline $\begin{array}{l}\text { The closest family employees are most likely } \\
\text { to give best job performance in your firm }\end{array}$ & 0.803 & 0.047 & 0.203 \\
\hline $\begin{array}{l}\text { Family employees tend to have higher job } \\
\text { performance than non-family employees }\end{array}$ & 0.795 & -0.034 & 0.278 \\
\hline $\begin{array}{l}\text { You always communicate face to face with } \\
\text { your relatives working in your firm }\end{array}$ & 0.767 & 0.242 & 0.137 \\
\hline $\begin{array}{l}\text { Family employees in your firm always pay } \\
\text { visit to each other }\end{array}$ & 0.751 & 0.293 & 0.105 \\
\hline $\begin{array}{l}\text { Employees who are your relatives or } \\
\text { classmates tend to give better performance } \\
\text { than other types of employees in your firm }\end{array}$ & 0.710 & -0.040 & 0.443 \\
\hline $\begin{array}{l}\text { You do not worry about tunneling behaviors of } \\
\text { your relatives in your firm }\end{array}$ & 0.654 & -0.047 & 0.106 \\
\hline $\begin{array}{l}\text { You have explicitly-defined compensation } \\
\text { schemes for your family employees }\end{array}$ & 0.007 & $\mathbf{0 . 8 2 7}$ & 0.189 \\
\hline $\begin{array}{l}\text { You have explicitly-defined job responsi- } \\
\text { bilities for your family employees }\end{array}$ & 0.431 & 0.722 & -0.087 \\
\hline $\begin{array}{l}\text { You have explicitly-defined option schemes } \\
\text { for your family employees }\end{array}$ & -0.031 & 0.687 & 0.298 \\
\hline $\begin{array}{l}\text { You regard long-tenure employees as family } \\
\text { and they enjoy certain status in your family } \\
\text { too }\end{array}$ & 0.075 & 0.051 & 0.810 \\
\hline $\begin{array}{l}\text { You "convert" excellent employees into } \\
\text { "insiders" and help them better manage your } \\
\text { firm }\end{array}$ & 0.301 & 0.237 & 0.587 \\
\hline $\begin{array}{l}\text { The more contribution a manager makes to } \\
\text { your firm, the more trust you lay on him/her }\end{array}$ & 0.228 & 0.205 & 0.528 \\
\hline Credibility & 0.896 & 0.665 & 0.539 \\
\hline AVE & 0.463 & 0.353 & 0.540 \\
\hline
\end{tabular}

Note: KMO is 0.863 , total variance explained is $62.635 \%$. Principal factor analysis and varimax orthogonal rotation methods are used. 


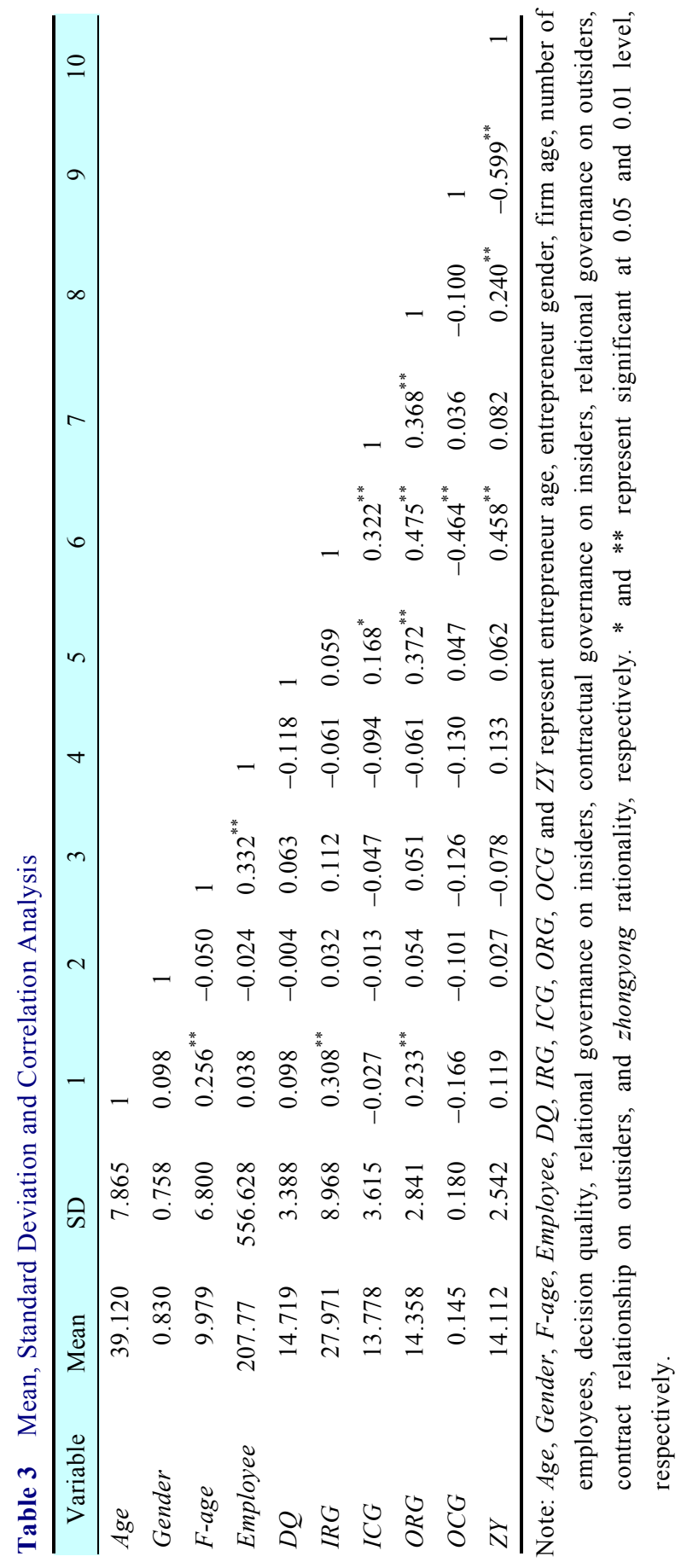


Table 4 Results of Regression Results

\begin{tabular}{|c|c|c|c|c|c|}
\hline Variable & $D Q$ & $\begin{array}{l}R G \text { on } \\
\text { insiders }\end{array}$ & $\begin{array}{l}C G \text { on } \\
\text { insiders }\end{array}$ & $\begin{array}{l}R G \text { on } \\
\text { outsiders }\end{array}$ & $\begin{array}{l}C G \text { on } \\
\text { outsiders }\end{array}$ \\
\hline \multicolumn{6}{|l|}{ Control variable } \\
\hline Firm age & 0.164 & 0.135 & 0.002 & 0.083 & $-0.160^{*}$ \\
\hline Employee & $-0.198^{*}$ & $-0.175^{*}$ & -0.128 & -0.120 & 0.032 \\
\hline Age & & $0.241^{* *}$ & -0.010 & $0.251^{* *}$ & -0.054 \\
\hline Gender & & -0.007 & -0.010 & 0.034 & -0.073 \\
\hline \multicolumn{6}{|l|}{$\begin{array}{l}\text { Independent } \\
\text { variable }\end{array}$} \\
\hline$R G$ on insiders & $-0.399^{* *}$ & & & & \\
\hline$C G$ on insiders & 0.147 & & & & \\
\hline$R G$ on outsiders & $0.414^{* *}$ & & & & \\
\hline$C G$ on outsiders & -0.002 & & & & \\
\hline$Z Y$ & & $0.494^{* *}$ & 0.075 & $0.351^{* *}$ & $-0.615^{* *}$ \\
\hline Change $R^{2}$ & $0.154^{* *}$ & $0.230^{* *}$ & 0.005 & $0.117^{* *}$ & $0.352^{* *}$ \\
\hline Overall $R^{2}$ & 0.155 & 0.329 & 0.019 & 0.196 & 0.391 \\
\hline
\end{tabular}

Note: $*$ and ${ }^{* *}$ represent significant at 0.05 and 0.01 levels, respectively.

\section{Conclusions and Discussion}

Our empirical results lend strong support to H1, H3 and H4. Particularly, we found that although relational governance on insiders is significantly and negatively related to decision quality, many family firms still prefer the governance mode to other modes. We think one can understand such a paradoxical finding better from the perspective of zhongyong rationality believed and practiced by many Chinese entrepreneurs. As the rationality is characterized by holistic view, self-restrain and appropriateness, it is the essence of oriental business ethics, a necessary step for gaining a deeper understanding of Chinese businessmen and family firms. Cheung et al. (2001) interviewed (in a rather informal way) many businessmen in mainland China, Hong Kong, Taiwan, Singapore and Malaysia, and found that interviewees holding zhongyong philosophy were more willing to maintain a subtle balance between business profit and good relationship with both insiders and outsiders.

In a culture characterized by a low level of social trust, a family-based governance mode is likely helpful for the early development of family firms. As family firms mature, the marginal utility of family-based governance will gradually decline, or even become negative. From a strictly utilitarian point of view, entrepreneurs in Chinese family firms shall abandon family-based governance mode and turn to contract-based modes. However, as Chinese people 
give priority to a harmonious relationship among family members, dismissal of "useless" family employees is regarded as a short-sighted and ingratitude behavior, hence giving rise to repulsion among all family members. Moreover, Chinese people are taught to "be prepared for danger in times of safety," they believe that in times of business crisis, family employees would be more loyal to each other than non-family employees, such a consideration also make them reluctant to dismiss those good-for-nothing family employees.

Meanwhile, Chinese entrepreneurs, under the guidance of zhongyong rationality, tend to carefully examine the characteristic merits and demerits of other types of governance modes. That is why most Chinese entrepreneurs give up stock option schemes for professional managers or contractual governance on outsiders. As pointed out by $\mathrm{Yu}$ (2008), zhongyong rationality highlights two principles of "jing" and "quan," the former refers to a general and absolute principle everyone must abide by; while "quan" refers to the principle of "act according to specific circumstances." Our empirical results demonstrate that Chinese family firms tend to adopt a pan-familism governance mode on professional managers, reflecting their abidance of "jing" in running family firms; meanwhile, they also retain relational governance on insiders, reflecting their abidance of "quan."

To conclude, it seems that Chinese familism is able to nurture a rational, contract-based governance mode. It is not a logoscentrism in an extreme state, but a combination of "jing" and "quan" principles in zhongyong rationality. We believe the differences in governance mode choice between Chinese family firms and their western peers are similar to that of the difference between western philosophy, which emphasizing an independent, objective and fair attitude towards things and Confucianism, which highlights the necessity to perceive external objects from one's truly inner self. We thus argue that the zhongyong rationality is a key to understanding the governance behaviors of Chinese family firms.

Acknowledgements This research is supported by the 211 Key Discipline Construction Project by Guangdong University of Foreign Studies. It is also supported by the National Natural Science Foundation of China (No. 70872118, 70732005).

\section{References}

Cheung, T. 张德胜, King, Y. C. 金耀基, Chan, H. M. 陈海文, Chan, K. M. 陈健民, Yang, C. 杨中芳, Chiu, C. 赵志裕, Thireau, I. 伊莎白. 2001. 论中庸理性: 工具理性、价值理性 和沟通理性之外 (On zhongyong rationality: Beyond instrumental rationality, value rationality and communication rationality). 社会学研究 (Sociology Studies), 16(2): 33-48.

Chiu, C. 赵志裕. 2000. 中庸思维的测量: 一项跨地区研究的初步结果 (On the measure 
for zhongyong rationality: Preliminary findings from a cross-regional survey). 香港社会科 学学报 (Hong Kong Journal of Social Sciences), (18): 33-55.

Dooley, R. S, \& Fryxell, G. E. 1999. Attaining decision quality and commitment from dissent: the moderating effects of loyalty and competence in strategic decision-making teams. Academy of Management Journal, 42(4): 389-402.

Feng, Y. 冯友兰. 2007. 冯友兰文集第4 卷 (Feng Youlan Corpus, vol. 4). 长春: 长春出版 社 (Chang Chun: Chang Chun Press).

Fornell, C., \& Larcker, D. F. 1981. Evaluating structural equation models with unobservable variables and measurement error. Journal of Marketing Research, 18(1): 39-50.

$\mathrm{He}, \mathrm{X}$., 何轩, Chen, W. 陈文婷, \& Li, X. 李新春. 2008. 赋予股权还是泛家族化? 家族企 业职业经理人治理的实证研究 (Future options or pan-familism? Evidence from professional managers in China's family firms). 中国工业经济(China Industrial Economy), 25(5): 109-119.

He, X. 何轩, \& Zhu, H. 朱沉. 2008. 利他主义、亲情寻租和家族企业治理 (Altruism, family rent-seeking, and governance on family firms). 外国经济与管理(Foreign Economics \& Management), 30(9): 28-33.

Jensen, M. C., \& Meckling W. H. 1976. Theory of the Firm: Managerial Behavior, Agency Costs and Ownership Structure .Journal of Financial Economics, 3(4): 305-360.

King, Y. 金耀基. 1992. 中国社会和文化 (Chinese society and culture). 香港: 牛津大学出 版社 (Hong Kong: Oxford University Press).

Liu, F. 刘风良, \& Jiang, T. 江艇. 2004. 行为宏观经济学的方法论意义 (Methodological meaning of behavioral macro-economics). 中国人民大学学报(Journal of Renmin University of China). 18(2): 39-45.

Mustakallio, M., Autio, E., \& Zahra, S. A. 2002. Relational and contractual governance in family firms: Effects on strategic decision making. Family Business Review, 9(3): 205-222.

Pan，B. 潘必胜. 2006. 理性、家族与中国现代化的路径依赖 (Rationality, Family and China's Path Dependency on Modernization). In 陈凌 (Ed.), 民营经济与中国家族企业成 长 (Private economy and growth of China's family firms). 北京: 经济科学出版社 (Beijing: Economic Science Press).

Podsakoff, P. M., MacKenzie, S. B., Lee, J., \& Podsakoff, N. P. 2003. Common method biases in behavioral research: A critical review of the literature and recommended remedies. Journal of Applied Psychology, 88: 879-903.

Schulze, W. S., Lubatkin, M. H., Dino, R. N., \& Buchholtz, A. K. 2001. Agency relationships in family firms: Theory and evidence. Organization Science, 12(2): 99-116.

Tversky, A., \& Kahneman, D. 1974. Judgment under uncertainty: Heuristics and biases. Science, 185: 1124-1131.

Weber, M. 1995. 儒教与道教 (The religion of China: Confucianism and Taoism). 北京:商务 印书馆 (Beijing: The Commercial Press).

Weber, M. 1997. 经济与社会 (上卷) (Economy \& Society (vol. 1)), 林荣远 (Trans.). 北京: 商务印书馆 (Beijing: The Commercial Press).

Yang, G. 杨光飞. 2006. 家族企业的“家族式治理”：人文制约抑或理性选择 (Family type of governance in family firms: Humane restraint or rational choice?) 江淮论坛 (Jianghuai Tribune),(4): 54-59.

Yang, C. 杨中芳. 1996. 如何研究中国人 (How to understand Chinese). 台北: 桂冠图书公 司 (Taipei: Laureate Publishing House).

Yang, C. 杨中芳. 2001. 中国人的世界观: 中庸实践思维初探 (World in Chinese people's eyes: On the practice of zhongyong rationality). In 如何理解中国人 (How to understand Chinese people): 269-286. 台北: 远流出版事业股份有限公司 (Taipei: Yuanliu Publishing 
House, Co., Ltd.).

Yang, C. 杨中芳, \& Chiu, C. 赵志裕. 1997. 中庸实践思维初探 (On the practice of zhongyong rationality). Unpublished dissertation.

$\mathrm{Yu}, \mathrm{Z}$. 余治平. 2008. 经权、常变的智慧——中庸之道的哲学根据 (Jinquan, constantly changing wisdom: Philosophical foundation for zhongyong rationality). 中山大学学报(社 科版) (Journal of Sun Yat-sen University (Social and Science Edition)), 48(1): 102-126.

Yu, Y. 余英时. 2005. 现代儒学的回顾与展望 (Review and prospects of modern Confucianism): 254-255. 上海: 三联书店 (Shanghai: Joint Publishing House).

Zhai, X. 翟学伟. 2001. 中国人的行动逻辑 (Behavior logics of Chinese people). 北京: 社 会科学文献出版社 (Beijing: Social Sciences Academic Press). 